Article

\title{
Sales Information System of Mobile Marketing at PT. World Innovative Telecommunication Using Up Selling, Cross Selling and Down Selling Methods
}

\author{
Eva $^{1}$, Benny Daniawan ${ }^{2}$, Aditiya Hermawan ${ }^{3}$ \\ ${ }^{1,2}$ Buddhi Dharma University, Information System, Banten, Indonesia \\ ${ }^{3}$ Buddhi Dharma University, Informatics Engineering, Banten, Indonesia
}

\section{SUBMISSION TRACK}

Recieved: Aug 21, 2020

Final Revision: Sept 18, 2020

Available Online: Sept 29, 2020

KEYWORD

Marketing System, Up Selling, Cross

Selling and Down Selling

CORRESPONDENCE

E-mail: evaeva9844@gmail.com

benny.daniawan@ubd.ac.id

\section{INTRODUCTION}

The development of human resources and information technology is accompanied by the development of the internet in the use of technology today needs each other so that it can produce an information technology. Information technology is widely used in various fields, especially in the field of sales. Pt. World Innovative Telecommunication is an electronic sales company based in Dongguan, Guangdong, and has a widespread office/subsidiary in the world, as one of its branches is located in Tangerang. In marketing and distribution of its products PT. World Innovative Telecommunication still uses a manual system, for example in mobile sales, most consumers buy it by coming directly to the store selling OPPO products, this way the buyer cannot know the stock

\section{A B S T T R A C T}

In the era of globalization the development of information system technology is very rapidly evolving and very affecting PT. World Innovative Telecommunication engaged in retail, namely mobile phones. Pt. World Innovative Telecommunication still does not have an online marketing and sales system that makes it difficult for consumers to know the products sold. The purpose of this system was to help PT. World Innovative Telecommunication in marketing, selling and increasing sales by using up selling, cross selling and down selling methods and providing convenience for consumers to get information about products sold as well as increase consumer satisfaction by using systems created and covered to unreachable areas. available in the store and the lack of information about the products he will buy, in the absence of this sales system consumers become made easy in ordering and disseminating information about existing products. The Internet is a comprehensive communication network and can connect all the hardware in the world even though the operating systems and machines are different [1]. Electronic Trading contains processes in sales, purchase, sending, exchange of goods, or information services by over the internet. The use and application of ECommerce will have a huge effect on large companies and have many subsidiaries or branches. Because everyone wants ease and speed to obtain and provide information without limited distance and time [2].Sales are a series of parts of the promotion that are the whole of one of the sales systems. Nowadays there 
are still many companies or trading businesses that do not use technology as a media information product, so this creates a lack of marketing and sales of products at the company or trading business itself due to marketing that does not cover many areas and limited reach. One to increase product marketing and sales covers many regions, namely by using information technology called E-Commerce [3].Marketing is a major component of the market, because the market is where sellers and buyers make transactions and are related to the customer's own decisions. The market is also very important for companies to offer goods and must follow competitors from companies that issue the same or similar products [3]. Information is data provided in a form that makes it easier in the activity to make a decision [4]. Such information has value in taking decisions to increase knowledge in certain areas of concern and help reduce obscurity [5]. UAT (User Acceptance Test) is a test conducted by the user that produces the output in the form of a test result document that is evidence that the software is acceptable and meets the needs of the user [6].

\section{LITERATURES REVIEW}

Based on previous research, Up Selling is a sales technique to attract customers to buy products that are more expensive than the products they want to make more profit, and can promote the products they own and make it easier for customers to transaction and get information about the products they want to buy and reach across the region [7].Cross Selling is a strategy that sells and offers other goods or services to consumers who have done to buy [8]. Discount is the nominal deducted from the original price given Strategy the customer purchases merchandise on credit [9].

\section{FRAMEWORK}

In order to design this system, a frame of mind is needed that is the main basis.

\begin{tabular}{|c|}
\hline Problem \\
\hline $\begin{array}{l}\text { Media marketing and sales information is } \\
\text { still offline. } \\
\text { - It does not yet have an online marketing and } \\
\text { sales system. } \\
\text { - Not yet using online information. }\end{array}$ \\
\hline$\downarrow$ \\
\hline Strategy \\
\hline $\begin{array}{ll}\text { - } & \text { Market products online. } \\
\text { - } & \text { Provide interesting ads. } \\
\text { - } & \text { Give a discount. } \\
\text { - } & \text { Offers complementary products. }\end{array}$ \\
\hline$\downarrow$ \\
\hline
\end{tabular}

\section{UP SELLING, CROSS SELLING AND DOWN SELLING METHODS}

- To make it easier to manage product sales data by computerized and stored in the database so that younger in printing sales reports. Introduce products sold easily and expand the marketing reach of products.

- To make it easier to manage product sales data by computerized and stored in the database so that younger in printing sales reports. Introduce products sold easily and expand the marketing reach of products.

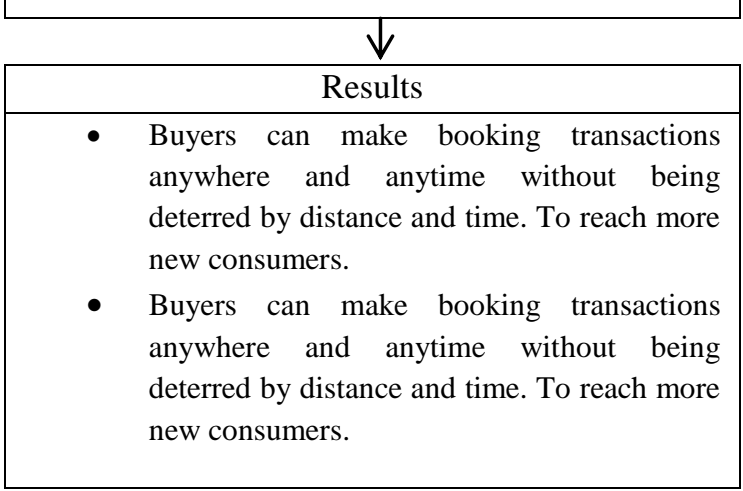

Figure 1. Think framework

\section{METHODS}

Up Selling, Cross Selling and Down Selling methods are methods used in PT. World Innovative Telecommunication in its online sales system. This method can help PT. World Innovative Telecommunication in marketing and selling its products to increase sales and gain more profit, in addition by using this method can also attract the attention of consumers. The following are the implementations of the following 3 methods: 
1. Showing OPPO products ads that are very interesting for consumers to see and buy them.

2. Displays products that are priced higher with better specifications than the product that the customer wants to purchase on the product details page when the consumer selects.

3. Display complementary products and accessories on the product details page so that consumers can complete the products they purchase.

4. Display and give discounts on old products or products that are difficult to sell to attract consumers to buy them.

To test the application of these three methods, the test was conducted by providing an online questionnaire.

The data collection of this testing system is to spread the questionnaire as a medium to find out the results of the E-Commerce system. We can find out the responses of 10 questions from the questionnaire results and shared with 54 respondents. Here are 10 questions raised:

Q1: This online marketing and sales system is very easy to find and get the products want?

Q2:This online marketing and sales system can provide information about the desired product?

Q3: This online marketing and sales system very

useful?

Q4: Do the ads on this system interest?

Q5: Can the appearance of similar products help to compare specifications with the products customers need?

Q6: The display of accessories products able to help complete the products customers need?

Q7: This online sales system is easy to access?

Q8: This online marketing and sales system is easy to use?

Q9: Do the types of products offered on this online marketing and sales system vary?

Q10: Using this online marketing and sales system make it easier to make transactions?

\section{RESULT}

System Testing using User Acceptance Test (UAT) The results are obtained by looking at the indicator below:
Table 1 Weighted Answer Value

\begin{tabular}{|l|c|}
\hline \multicolumn{1}{|c|}{ Answer } & Weights \\
\hline A : Very Agreeable & 5 \\
\hline B : Agree & 4 \\
\hline C : Neutral & 3 \\
\hline D : Disagree & 2 \\
\hline E : Strongly Disagree & 1 \\
\hline
\end{tabular}

The test was conducted by giving 10 questions to 54 respondents to find out the response to the system to be implemented. Here are the responses from 54 respondents:

Table 2 Response Results from 54 Respondents

\begin{tabular}{|c|c|c|c|c|c|c|c|c|c|c|c|}
\hline \multirow{2}{*}{ No } & \multirow{3}{*}{ Questions } & \multicolumn{4}{|c|}{ Answer } & \multicolumn{5}{|c|}{ Percentage } \\
\cline { 5 - 12 } & & A & B & C & D & E & A & B & C & D & E \\
\hline 1 & Q1 & 34 & 18 & 1 & 0 & 1 & $63 \%$ & $33,3 \%$ & $1,9 \%$ & $0 \%$ & $1,9 \%$ \\
\hline 2 & Q2 & 29 & 21 & 3 & 1 & 0 & $53,7 \%$ & $38,9 \%$ & $5,6 \%$ & $1,9 \%$ & $0 \%$ \\
\hline 3 & Q3 & 35 & 16 & 2 & 1 & 0 & $64,8 \%$ & $29,6 \%$ & $3,7 \%$ & $1,9 \%$ & $0 \%$ \\
\hline 4 & Q4 & 16 & 25 & 10 & 3 & 0 & $29,6 \%$ & $46,3 \%$ & $18,5 \%$ & $5,6 \%$ & $0 \%$ \\
\hline 5 & Q5 & 25 & 26 & 2 & 0 & 1 & $46,3 \%$ & $48,1 \%$ & $3,7 \%$ & $0 \%$ & $1,9 \%$ \\
\hline 6 & Q6 & 18 & 25 & 8 & 2 & 1 & $33,3 \%$ & $46,3 \%$ & $14,8 \%$ & $3,7 \%$ & $1,9 \%$ \\
\hline 7 & Q7 & 23 & 23 & 6 & 1 & 1 & $42,6 \%$ & $42,6 \%$ & $11,1 \%$ & $1,9 \%$ & $1,9 \%$ \\
\hline 8 & Q8 & 24 & 24 & 4 & 1 & 1 & $44,4 \%$ & $44,4 \%$ & $7,4 \%$ & $1,9 \%$ & $1,9 \%$ \\
\hline 9 & Q9 & 22 & 23 & 8 & 0 & 1 & $40,7 \%$ & $42,6 \%$ & $14,8 \%$ & $0 \%$ & $1,9 \%$ \\
\hline 10 & Q10 & 35 & 14 & 3 & 2 & 0 & 64,85 & $25,9 \%$ & $5,6 \%$ & $3,7 \%$ & $0 \%$ \\
\hline
\end{tabular}

Here's the weight of the scores of the 10 questions that 54 respondents have answered:

Table 3 Answer Value Weights of 54 Respondents

\begin{tabular}{|c|c|c|c|c|c|c|c|}
\hline \multirow{2}{*}{ No } & \multirow{2}{*}{ Questions } & \multicolumn{5}{|c|}{ Value } & Amount \\
\cline { 3 - 8 } & & Ax5 & Bx4 & Cx3 & Dx2 & Ex1 & \\
\hline 1 & Q1 & 170 & 72 & 3 & 0 & 1 & 246 \\
\hline 2 & Q2 & 145 & 84 & 9 & 2 & 0 & 240 \\
\hline 3 & Q3 & 175 & 64 & 6 & 2 & 0 & 247 \\
\hline 4 & Q4 & 80 & 100 & 30 & 6 & 0 & 216 \\
\hline 5 & Q5 & 125 & 104 & 6 & 0 & 1 & 236 \\
\hline 6 & Q6 & 90 & 100 & 24 & 4 & 1 & 219 \\
\hline 7 & Q7 & 115 & 92 & 18 & 2 & 1 & 228 \\
\hline 8 & Q8 & 120 & 96 & 12 & 2 & 1 & 231 \\
\hline 9 & Q9 & 110 & 92 & 24 & 0 & 1 & 227 \\
\hline 10 & Q10 & 175 & 56 & 9 & 4 & 0 & 244 \\
\hline
\end{tabular}

The table above is a calculation of the processing of questionnaire data that has been answered by the user and collected for the analysis of the percentage calculation of each question. The amount earned by calculating each value in Table 2 is multiplied by 
Table 1. If you have already obtained a value from multiplication of Table 2 with Table 1 then the calculation is carried out to find out the total weight of the value of each question.

To get the number one question value by way of the table above can be seen the number of values from 54 respondents for the first question is 246 . The average value is $246 / 54=4.55$. The percentage value is $4.55 / 5$ x $100=91 \%$. To get the number one question value by way of the table above can be seen the number of values from 54 respondents for the first question is 246. The average value is $246 / 54=4.55$. The percentage value is $4.55 / 5 \times 100=91 \%$.

After disseminating 10 questions that have been filled by 54 respondents, it can be known the average value as follows:

Table 4 Average values

\begin{tabular}{|c|r|}
\hline Questions & Percentage \\
\hline 1 & $91,0 \%$ \\
\hline 2 & $88,8 \%$ \\
\hline 3 & $91,2 \%$ \\
\hline 4 & $80,0 \%$ \\
\hline 5 & $87,4 \%$ \\
\hline 6 & $82,0 \%$ \\
\hline 7 & $84,0 \%$ \\
\hline 8 & $84,0 \%$ \\
\hline 9 & $84,0 \%$ \\
\hline 10 & $90,4 \%$ \\
\hline Total & $\mathbf{8 4 \%}$ \\
\hline
\end{tabular}

From the above data can be known, that the information system of marketing and sales of mobile phones at PT. World Innovative Telecommunication using up selling, cross selling and down selling methods has a userfriendly look, the menus contained in the system are easy to understand and the contents or information are easy to understand.

\section{Program View}

After designing the program then here is the implementation of the display of the program that has been created:

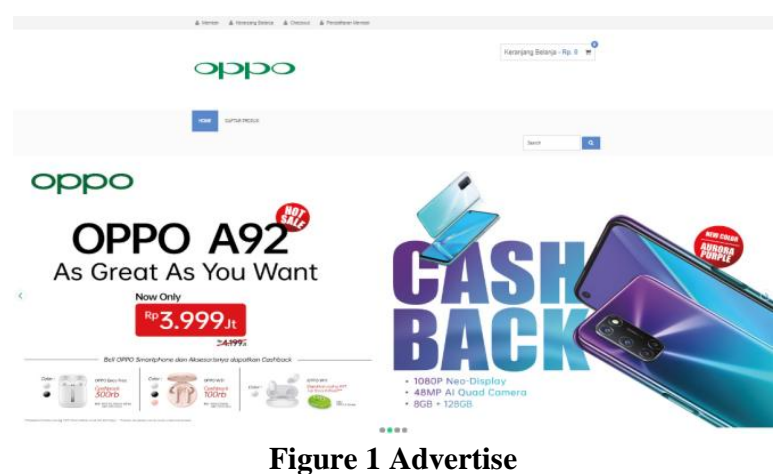

This page displays the home page before member registration or login. This page also shows ads and products that are marketed and for sale.

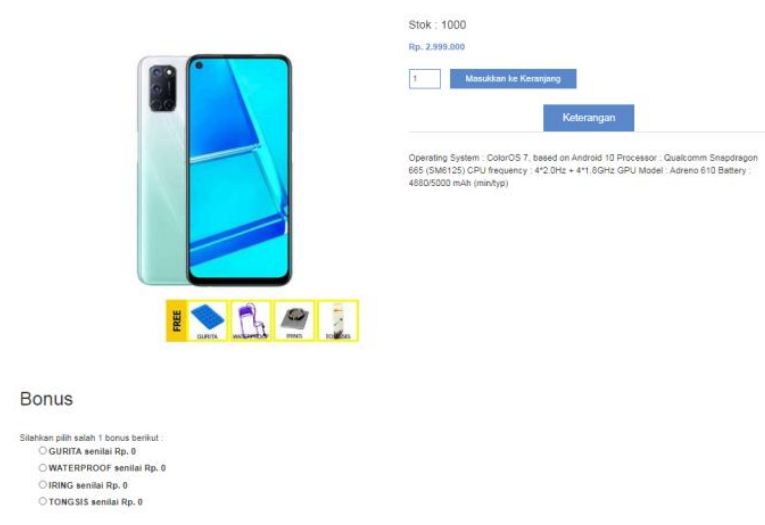

Figure 2 Product Details Page

This page displays a list of products marketed for sale with existing stock and provides bonuses to attract consumers.

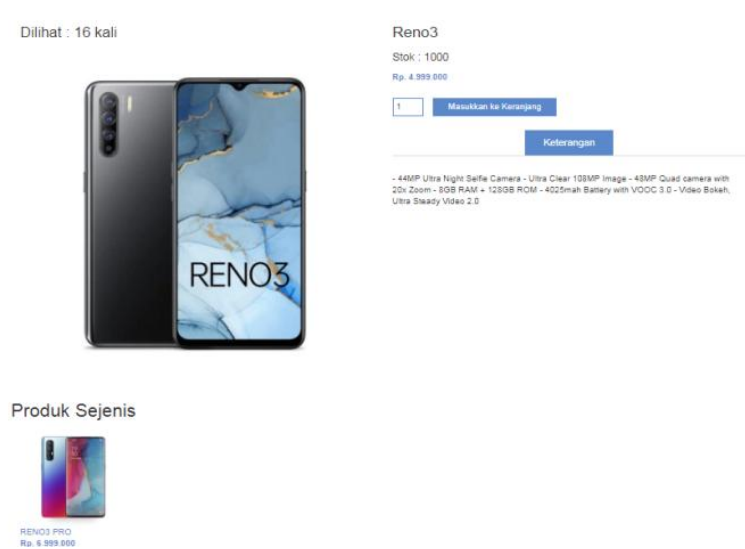

Figure 3 Similar Product Pages

For this page displays product details, such as product specifications, product stock, product prices and also displays similar products with not much different product specifications and prices. 


\section{CONCLUSION}

Based on the existing problems, it can be concluded the problem solving as follows:

1. The system created will be very helpful in marketing and selling online so that consumers easily get the desired product.

2. By using the system created it will increase the satisfaction of the users.

3. By using the system created, online marketing and sales will reach unreachable area.

\section{REFERENCES}

[1] D. Ahmadi, Candra; Hermawan, E-Business \& E-commerce. Yogyakarta: Andi, 2013.

[2] D. C. Turban, Efraim; King, David; Lee, Jae Kyu; Liang, Ting-Peng; Turban, Electronic Commerce: A Managerial and Social Networks Perspective, 8th ed. Springer International Publishing Switzerland 2015, 2015.

[3] F. Abdullah, Thamrin; Tantri, Manajemen Pemasaran. Jakarta: PT. Raja Grafindo Persada, 2016.

[4] M. S. J. Sumarni, Pengantar Bisnis (Dasar-Dasar Ekonomi Perusahaan), 6th ed. Yogyakarta: Liberty, 2010.

[5] P. Ulric J, Gelinas; Richard B, Dull; Wheller, Accounting Information Systems 9th Edition. South Western: Cengage Learning, 2011.

[6] E. Chaya Permana, "Pengujian UAT (User Acceptance System)," 2017. [Online]. Available: https://endangcahyapermana.wordpress.com/2017/03/14/pengujian-uat-user-acceptance-test/.

[7] F. Purwaningtias, "Strategi Up Selling Pada Website Penjualan," Simetris J. Tek. Mesin, Elektro dan Ilmu Komput., vol. 9, no. 1, pp. 109-120, 2018.

[8] C. Bisnis, "Strategi Penerapan Up Selling, Down Selling, dan Cross Selling Untuk Meningkatkan Omset Penjualan," 2018. [Online]. Available: https://celotehbisnis.com/strategi-penerapan-up-selling-downselling-dan-cross-selling-untuk-meningkatkan-omset-penjualan/. [Accessed: 05-Apr-2020].

[9] H. Simamora, Manajemen Pemasaran Internasional Jilid 2. Jakarta: Salemba E,pat, 2000.

\section{BIOGRAPHY}

Eva, Graduated in Information System Study Program from Buddhi University in 2020, currently an employee at PT. World Innovative Telecommunication.

Benny Daniawan, Graduated in Information Engineering Study Program (S1) in Network, 2011, Computer Science Study Program (S2) in Information Systems, 2016. Currently as a lecturer in the Information System Study Program, Buddhi Dharma University.

Aditiya Hermawan, Graduated in the Informatics Engineering Study Program (S1) in 2010, continued his Masters in Computer Science in 2011 and graduated in 2013. He is currently a Lecturer Informatics Engineering Study Program in Buddhi Dharma University. 